\title{
Sistem Pendukung Keputusan Perusahaan yang Berprestasi dalam Sektor Indutri dengan Metode Weighted Product
}

\author{
Nunik Destria $^{1)}$, Indriyani $^{2)}$,Sudin Saepudin ${ }^{3)}$ \\ 1,) Universitas NusaPutra Jl. Cibolang kalrer Cibadak Kab. Sukabumi \\ e-mail: niunik.destria@nusaputra.ac.id ${ }^{1}$, Indriyani@gmail.com ${ }^{2}$ sudin.saepudi@nusaputra.ac.id ${ }^{3}$ \\ * Korespondensi: e-mail: niunik.destria@nusaputra.ac.id
}

\begin{abstract}
ABSTRAK
The importance of determining an outstanding company is to give awards every year or every anniversary of Sukabumi Regency. Then with the award can encourage every company to continue to increase the company it runs. However, the problem contained in DPMPTSP Kabupaten is in the determination of companies that perform well still done conventionally or seen from the data of field reviews. Therefore, a decision support system is needed in determining the company that excels by using weighted product method. Weighted product method is to use multiplication to connect attribute rating where the rating of each attribute must be increased first with the weight in question. This decision support system is a tool that can provide solutions and help the service in the process of determining companies that excel computerized in order to be faster and more precise. The results prove that this application is able to assist the service in the selection process of determining the company's achievements by weight product method, as well as providing information on outstanding companies effectively and efficiently with a percentage of user testing of $76.66 \%$.
\end{abstract}

Keywords : Decision Support System, Weighted Product, Outstanding Company

\section{ABSTRACT}

Pentingnya menentukan perusahaan yang berprestasi yakni untuk memberikan penghargaan setiap tahunnya atau setiap ulang tahun Kabupaten Sukabumi. Kemudian dengan adanya penghargaan tersebut dapat mendorong setiap perusahaan untuk terus meningkat perusahaan yang dijalankannya. Namun masalah yang terdapat pada DPMPTSP Kabupaten yaitu dalam penentuan perusahaan yang berprestasi masih dilakukan secara konvensional atau dilihat dari data hasil peninjauan lapangan. Oleh karena itu diperlukanlah sebuah sistem pendukung keputusan dalam penentuan perusahaan yang berprestasi dengan menggunakan metode weighted product. Metode weighted product yaitu menggunakan perkalian untuk menghubungkan rating atribut dimana rating setiap atribut harus dipangkatkan dulu dengan bobot yang bersangkutan. Sistem pendukung keputusan ini merupakan alat bantu yang dapat memberikan solusi dan membantu dinas dalam proses penentuan perusahaan yang berprestasi secara komputerisasi agar lebih cepat dan tepat. Hasil penelitian membuktikan bahwa aplikasi ini mampu membantu dinas dalam proses seleksi penentuan perusahaan berprestasi dengan metode weight product, serta memberikan informasi perusahaan berprestasi secara efektif dan efisien dengan presentase pengujian pengguna sebesar 76,66 \% .

Kata Kunci : Sistem Pendukung Keputusan, Weighted Product, Perusahaan berprestasi. 


\section{Pendahuluan}

DOKUMEN ini adalah template untuk Microsoft Word. Dokumen ini diadaptasi dari template jurnal IEEE dan disesuaikan untuk JURSITEMTEK. Semu artikel yang akan dipublikasikan di JURSITEMTEK harus memenuhi template ini. Semua gaya tulisan (termasuk judul bab dan judul gambar/tabel telah disediakan pada dokumen ini. Gunakan gaya tulisan ini untuk melakukan penulisan. Pada saat ini perkembangan teknologi informasi sudah sedemikian pesat. Perkembangan yang pesat tidak hanya teknologi perangkat keras dan perangkat lunak saja, tetapi metode komputasi juga ikut berkembang. Salah satu metode komputasi yang cukup berkembang saat ini adalah metode sistem pendukung keputusan (Decisions Support System).

Salah satu permasalahan pendukung keputusan yang dihadapkan pada berbagai kriteria adalah proses penentuan perusahaan yang berprestasi dari beberapa sektor salah satunya sektor industri di Kabupaten Sukabumi yang di tentukan oleh DPMPTSP Kabupaten Sukabumi.

DPMPTSP adalah Dinas Penanaman Modal dan Pelayanan Terpadu Satu Pintu yaitu sebagai penghubung utama antara dunia usaha dan pemerintahan, DPMPTSP diberi mandat untuk mendorong investasi langsung, baik dari dalam negeri maupun luar negeri, melalui penciptaan iklim investasi yang kondusif.

Permasalahan yang muncul dari DPMPTSP Kabupaten Sukabumi yaitu untuk menentukan perusahaan yang berprestasi dari beberapa sektor salah satunya adalah sektor industri masih dilakukan secara konversional dan dilihat dari data hasil peninjauan lapangan. Kemudian untuk menentukan perusahaan yang berprestasi memerlukan waktu yang cukup dengan jumlah data yang sangat banyak.

Melihat dari permasalahan tersebut, hal ini dapat diatasi dengan model MADM. MADM (Multiple Atribut Decision Making) memiliki beberapa metode yang bisa digunakan untuk menyelesaikan masalah salah satunya yaitu dengan menggunakan metode Weighted Product (WP).

Sedangkan dalam penelitian sebelumnya yang berjudul "Sistem Pendukung Keputusan Dalam Pemilihan Karyawan Terbaik Di PT.Smartlink Global Media Dengan Metode Weighted Product". bahwa grafik kuesioner karyawan dapat disimpulkan sebagian besar responden sangat setuju dengan adanya sistem pendukung keputusan pemilihan karyawan terbaik dengan metode weighted product. Dalam penelitian tersebut mendapatkan koresponden dengan nilai 97,5\% karena membuat proses pengumpulan dan pencarian data menjadi lebih cepat dan efisien dan dapat digunakan dalam melakukan pemilihan karyawan terbaik.

Diharapkan dengan adanya metode tersebut dapat menjadi solusi dari permasalah penentuan perusahaan yang berprestasi, dimana dengan menggunakan metode tersebut dapat menentukan perusahaan berdasarkan kriteria yang ada, untuk menciptakan hal tersebut perlu dibuatnya suatu sistem pendukung keputusan.

\section{Penelitian Terkait}

\subsection{Penelitian Terkait}

Dalam penelitian yang berjudul "Sistem Pendukung Keputusan Pemilihan Dosen Terbaik dengan Metode Weighted Product (WP) Pada Stmik Royal" oleh (Nasrun Marpaung, Masitah Handayani, Rolly Yesputra, 2018). Peran penting dosen bagi perguruan tinggi sangatlah mempengaruhi kualitas mahasiswa yang akan dihasilkan menciptakan mahasiswa yang berkompeten dibidangnya. Sehingga perlu dibuat sebuah penghargaan untuk menunjang semangat bersaing dalam segi kualitas dosen dan akan dipilih sebagai dosen terbaik. Dalam pemilihan dosen terbaik tentunya membutuhkan sebuah sistem pendukung keputusan yang dapat mengolah data untuk menentukan dosen yang dianggap terbaik. Variabel yang digunakan yaitu Penilaian Mahasiswa, Penilaian Dosen Sejawat, Penilaian Atasan/Manajemen, Kualifikasi Pendidikan, Penelitian, Jurnal yang diterbitkan, Pelatihan/ Kursus, Seminar yang diikuti, Pengabdian kepada Masyarakat, Jabatan Akademik/Fungsional. Dengan menerapkan metode Weight Product pada sistem pengolahan data tentunya menghasilkan nilai keputusan yang lebih akurat dan menghasilkan nilai yang sama antara hitungan manual dan nilai pada sistem.

Kemudian dalam penelitian yang berjudul "Sistem Pendukung Keputusan Penilaian Dosen Berprestasi Menggunakan Weighted Product (WP) di STIKES Alma Ata Yogyakarta" oleh (Cicik Sulastri, Sri Siswanti, Andriani KKW) permasalah yang muncul yaitu proses penilaian untuk dosen berprestasi di 
STIKES Alma Ata Yogyakarta masih menggunakan cara manual, yaitu dengan mengumpulkan data penilaian seluruh dosen dan harus menjumlahkan semua nilai yang terkumpul dari setiap dosen sehingga membutuhkan waktu cukup lama dalam perhitungannya. Kriteria yang digunakan yaitu Voting seluruh karyawan, Penilaian rekan kerja, Presensi Kehadiran, Penelitian, Pengajaran, Pengabdian masyarakat, Penilaian oleh pimpinan, Penilaian oleh yayasan. Metode untuk menangani masalah tersebut dapat menggunakan metode Weighted Product (WP) Sistem pendukung keputusan penilaian dosen berprestasi dengan metode weighted product ini dapat memberikan perangkingan dan tingkat akurasi mencapai $80 \%$.[4]

\subsection{Sistem Pendukung Keputusan}

Sistem Pendukung Keputusan merupakan sistem informasi interaktif yang menyediakan informasi, pemodelan, dan pemanipulasi data. Sistem itu digunakan untuk membantu pengambilan keputusan dalam situasi semiterstruktur dan situasi yang terstruktur, dimana tak seorang pun tahu secara pasti bagaimana keputusan seharusnya dibuat (Kusrini, 2007).[9]

Dengan pengertian diatas dapat dijelaskan bahwa sistem pendukung keputusan bukan merupakan alat pengambilan keputusan melainkan sistem yang dapat membantu pengambil keputusan. Dengan dilengkapinya informasi dari data yang telah diolah secara relevan maka diperlukan untuk membuat keputusan tentang suatu masalah secara lebih cepat dan akurat sehingga sistem ini tidak dimaksudkan untuk menggantikan pengambilan keputusan dalam proses pembuatan keputusan.

\subsection{Model Waterfall}

Metode Waterfall adalah suatu proses pengembangan perangkat lunak berurutan, di mana kemajuan dipandang sebagai terus mengalir melewati fase-fase perencanaan, pemodelan, implementasi (konstruksi), dan pengujian. Berikut adalah gambar pengembangan perangkat lunak berurutan/ linear. Berikut tahapan metode waterfall :

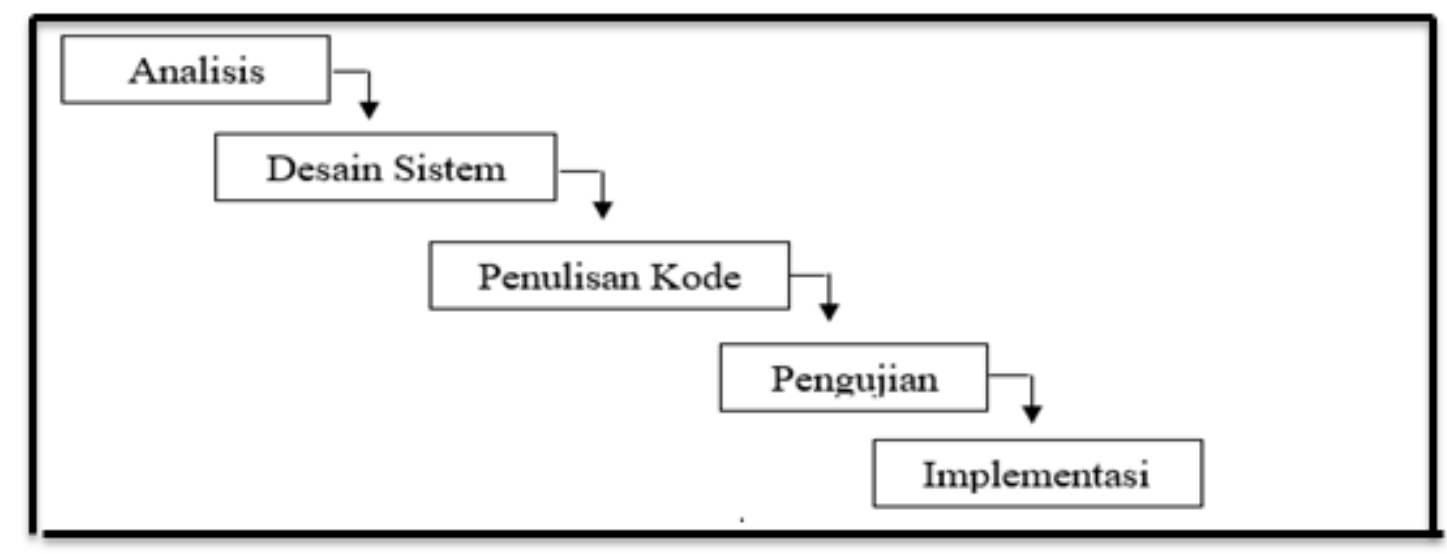

Gambar 1 Tahapan Model Waterfall

1. Analisis Kebutuhan (Requirement)

Langkah ini merupakan analisa terhadap kebutuhan sistem. Pengumpulan data dalam tahap ini bisa melakukan sebuah penelitian, wawancara atau study literatur. Seseorang sistem analisis akan menggali informasi sebanyak-banyaknya dari user sehingga akan tercipta sebuah sistem komputer yang bisa melakukan tugas-tugas yang diinginkan oleh user tersebut. Tahapan ini akan menghasilkan dokumen user requirement, dokumen inilah yang akan menjadi acuan sistem analisis untuk menterjemahkan kedalam bahasa pemograman.

2. Desain Sistem (Design System)

Proses desain akan menterjemahkan syarat kebutuhan kesebuah perancangan perangkat lunak yang dapat diperkirakan sebelum dibuat koding. Proses ini berfokus pada : struktur data, arsitektur perangkat lunak, representasi interface, dan detail (algoritma) prosedural. Tahapan ini 
Hal 1 - 11 ISSN. P: 2715-1875, E: 2715-1883

akan menghasilkan dokumen yang disebut software requirement. Dokumen inilah yang akan digunakan programmer untuk melakukan aktivitas pembuatan sistemnya.

3. Penulisan Kode Program (Coding)

Penulisan kode program atau coding merupakan penerjemahan desain dalam bahasa yang bisa dikenali oleh komputer. Dilakukan oleh programmer yang akan meterjemahkan transaksi yang diminta oleh user. Tahapan ini lah yang merupakan tahapan secara nyata dalam mengerjakan suatu sistem. Dalam artian penggunaan komputer akan dimaksimalkan dalam tahapan ini. Setelah pengkodean selesai maka akan dilakukan testing terhadap sistem yang telah dibuat tadi. Tujuan testing adalah menemukan kesalahan-kesalahan terhadap sistem tersebut dan kemudian bisa diperbaiki.

4. Pengujian Program (Testing)

Tahapan akhir dimana sistem yang baru diuji kemampuan dan keefektifannya sehingga didapatkan kekurangan dan kelemahan sistem yang kemudian dilakukan pengkajian ulang dan perbaikan terhadap aplikasi menjadi lebih baik dan sempurna.

5. Pemeliharaan (Maintenance)

Pemeliharaan suatu software diperlukan, termasuk di dalamnya adalah pengembangan, karena software yang dibuat tidak selamanya hanya seperti itu. Ketika dijalankan mungkin saja masih ada error kecil yang tidak ditemukan sebelumnya, atau ada penambahan fitur-fitur yang belum ada pada software tersebut. Pengembangan diperlukan ketika adanya perubahan dari eksternal perusahaan seperti ketika ada pergantian sistem operasi, atau perangkat lainnya. [16]

\subsection{Weighted Product}

Metode Weighted Product adalah salah satu metode penyelesaian masalah pada MADM. Metode ini mengevaluasi beberapa alternatif terhadap sekumpulan atribut atau kriteria, dimana setiap atribut saling tidak bergantung satu dengan yang lainnya (Kusumadewi, 2006). Dalam penentuan nilai kepentingan atau bobot pada aplikasi sistem pendukung keputusan sebagai alat bantu, pencarian nilai bobot atribut menggunakan penilaian secara subyektif yaitu dengan diberi peringkat 1 sampai 5 berdasarkan jenis dan beberapa kriteria yang telah dipilih sebelumnya. Metode weighted product menggunakan perkalian untuk menghubungkan rating atribut, dimana rating setiap atribut harus dipangkatkan dulu dengan bobot yang bersangkutan. Proses ini sama halnya dengan proses normalisasi.[13]

\subsection{Kerangka Berfikir}

Adapun kerangka berfikir dalam penelitian ini ialah sebagai berikut ini :

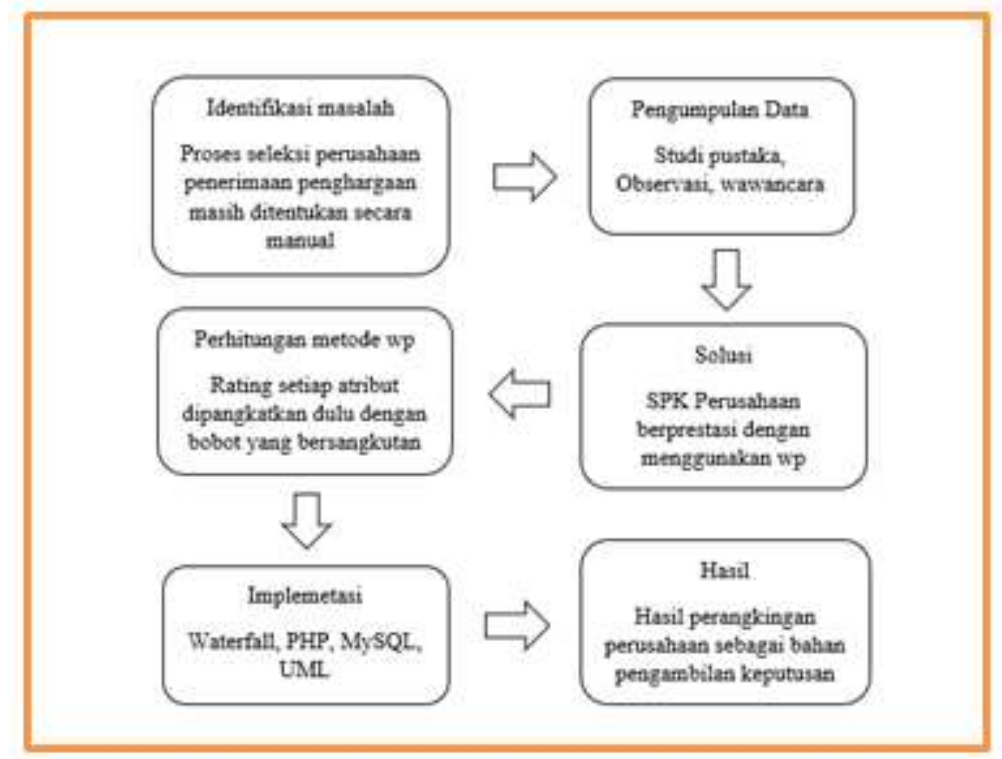

Gambar 2 Karangka berfikir 


\section{Metodelogi Penelitian}

\subsection{Teknik Pengumpulan Data}

Dalam penelitian ini, diperlukan data-data serta informasi dan referensi sebagai bahan yang dapat mendukung materi uraian dan pembahasan. Metode pengumpulan data yang dilakukan dalam penelitian ini sebagai berikut:

\subsubsection{Studi Pustaka}

Studi pustaka diperlukan untuk memilih data dan informasi yang berkaitan dengan penelitian yang menggunakan metode Weighted Product serta model Waterfall untuk mengembangkan sistem dan dapat membantu menyelesaikan masalah. Tahap ini dilakukan dengan menelusuri literatur yang ada serta menelaahnya secara tekun. Maka harus memperoleh orientasi yang lebih luas dalam permasalahannya yang dipilih serta menghindari terjadinya duplikasi yang tidak diinginkan.

\subsubsection{Wawancara}

Wawancara ini dilakukan dengan cara melakukan diskusi dengan pak Dudy Sukarta selaku Kasi Kebijakan dan Pengembangan Penanaman Modal di DPMPTSP Kabupaten Sukabumi. Wawancara ini dilakukan dengan mengajukan pertanyaan mengenai segala kebutuhan yang diperlukan dalam pembuatan sistem pendukung keputusan perusahaan yang berprestasi sehingga dapat mengetahui kebutuhan yang diperlukan dalam membangun sistem pendukung keputusan perusahaan yang berprestasi dalam sektor industri di Kabupaten Sukabumi.

\subsubsection{Observasi}

Observasi dilakukan untuk memperoleh data-data apa saja yang digunakan dalam sistem pendukung keputusan perusahaan yang berpresasi seperti data hasil peninjauan lapangan perusahaan dalam sektor industri.

\subsection{Jenis Data}

Data yang digunakan dalam penelitian ini adalah :

1. Data Kuantitatif Yaitu data atau informasi yang diperoleh dari dinas berupa dokumen - dokumen tentang penentuan perusahaan yang berprestasi, dokumen ini berupa data yang diperoleh dalam bentuk angkaangka. Data kuantitatif dalam penelitian ini bersumber dari DPMPTSP Kabupaten Sukabumi.

2. Data Kualitatif

Yaitu data yang diperoleh dari DPMPTSP Kabupaten Sukabumi dalam bentuk informasi yang bukan dalam bentuk angka tetapi dalam bentuk lisan dan tertulis. Data kualitatif ini seperti sejarah berdirinya serta visi-misi DPMPTSP Kabupaten Sukabumi.

\section{HaSil dan PEMbahasan}

\subsection{Hasil penelitian}

Hasil penelitian berisi implementasi metode weighted product didalam sistem pendukung keputusan perusahaan yang berprestasi dalam sektor industri di Kabupaten Sukabumi. Sistem pendukung keputusan didapat dari analisa dan desain sistem pada bab sebelumnya. Data dihitung dengan menggunakan software microsoft excel. Setelah mendapatkan hasil dari perhitungan, hasil tersebut dimasukan secara terkomputerisasi dalam bentuk sistem pendukung keputusan. Kemudian dilakukan pengujian dengan menggunakan blackbox testing dan di uji oleh pengguna. 


\subsection{Perhitungan metode weighted product}

Perhitungan menggunakan metode weighted product dengan tahapan sebagai berikut :

a. Diketahui kriteria yang digunakan beserta nilai bobot yang sudah ditetukan yaitu sebagai berikut:

Table 1 Bobot

\begin{tabular}{|c|l|c|}
\hline Kode & \multicolumn{1}{|c|}{ Nama } & Bobot \\
\hline C1 & Penanaman modal & 5 \\
\hline C2 & LKPM & 4 \\
\hline C3 & Jumlah Tenaga Kerja & 3 \\
\hline C4 & Pengelolaan Limbah & 2 \\
\hline C5 & Kewajiban Sosial & 2 \\
\hline C6 & Jenis Gaji & 1 \\
\hline
\end{tabular}

Dalam perhitungan metode weighted product dilakukan perbaikan bobot terlebih dahulu. Dengan perhitungan sebagai berikut:

$$
\begin{aligned}
& W_{1}=\frac{5}{5+4+3+2+2+1}=\frac{5}{17}=0,2941 \\
& W_{2}=\frac{4}{5+4+3+2+2+1}=\frac{4}{17}=0,2353 \\
& W_{3}=\frac{3}{5+4+3+2+2+1}=\frac{3}{17}=0,1765 \\
& W_{4}=\frac{2}{5+4+3+2+2+1}=\frac{2}{17}=0,1176 \\
& W_{5}=\frac{2}{5+4+3+2+2+1}=\frac{2}{17}=0,1176 \\
& W_{6}=\frac{1}{5+4+3+2+2+1}=\frac{1}{17}=0,0588
\end{aligned}
$$

Selanjutnya penentuan nilai vektor Si dengan melakukan perhitungan sebagai berikut:

$S_{1}=\left(3^{0,2941}\right)\left(5^{0,2353}\right)\left(4^{0,1765}\right)\left(2^{0,1176}\right)\left(4^{0,1176}\right)\left(5^{0,0588}\right)=3,6174$

$S_{2}=\left(3^{0,2941}\right)\left(5^{0,2353}\right)\left(4^{0,1765}\right)$

$\left(2^{0,1176}\right)\left(3^{0,1176}\right)\left(2^{0,0588}\right)=3,3136$

$S_{3}=\left(3^{0,2941}\right)\left(5^{0,2353}\right)\left(4^{0,1765}\right)$

$\left(2^{0,1176}\right)\left(3^{0,1176}\right)\left(4^{0,0588}\right)=3,4515$

Kemudian dilakukan perhitungan untuk mencari nilai vektor $\mathrm{Vi}$ atau nilai akhir, dengan perhitungan sebagai berikut:

$$
\begin{aligned}
& V_{1}= \frac{3,6174}{3,6174+3,3136+3,4515+\ldots+3,5901} \\
&= \frac{3,6174}{137,0733} \\
& V_{2}= \frac{3,6174}{3,6174+3,3136+3,4515+\ldots+3,5901} \\
&=\frac{3,3136}{137,0733}
\end{aligned}
$$




$$
\begin{gathered}
=0,0242 \\
V_{3}=\frac{3,4515}{3,6174+3,3136+3,4515+\ldots+3,5901} \\
=\frac{3,4515}{137,0733} \\
=0,0252
\end{gathered}
$$

b. Hasil rangking perusahaan berprestasi dari peringkat 1-10 yang menggunakan metode weighted product dengan perhitungan di microsoft excel.

Tabel 2 Hasil Rangking Perusahaan Berprestasi

\begin{tabular}{|c|l|c|}
\hline No & \multicolumn{1}{|c|}{ Nama Perusahaan } & Rangking \\
\hline 1 & PT. Pampas Indonesia & 1 \\
\hline 2 & Dong Jaya Mingkuk & 2 \\
\hline 3 & Tirta Purbalingga Adijaya & 3 \\
\hline 4 & Bio Sarana Indonesia & 4 \\
\hline 5 & Indolakto & 5 \\
\hline 6 & Kino Indonesia Tbk & 7 \\
\hline 7 & Ichi Tan Indonesia & 8 \\
\hline 8 & Amerta Indah Outsuka & 10 \\
\hline 9 & Longvin Indonesia & 9 \\
\hline 10 & Promedraharjo Farmasi Industri & \\
\hline
\end{tabular}

Berikut Grafik hasil rangking perusahaan yang berprestasi menggunakan metode weighted product: 


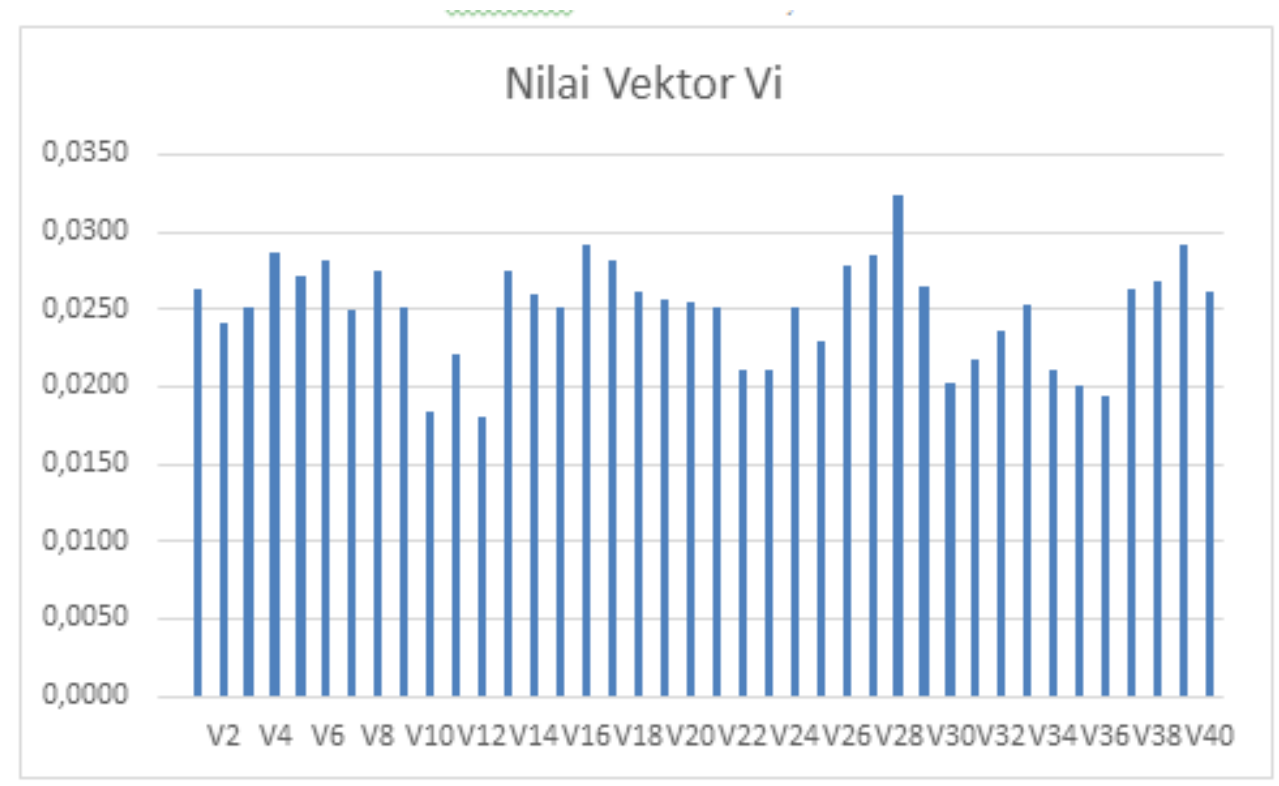

Gambar 3. grafik sistem pendukung keputusan

\subsection{Perancangan Sistem}

\section{a. Use Case Diagram}

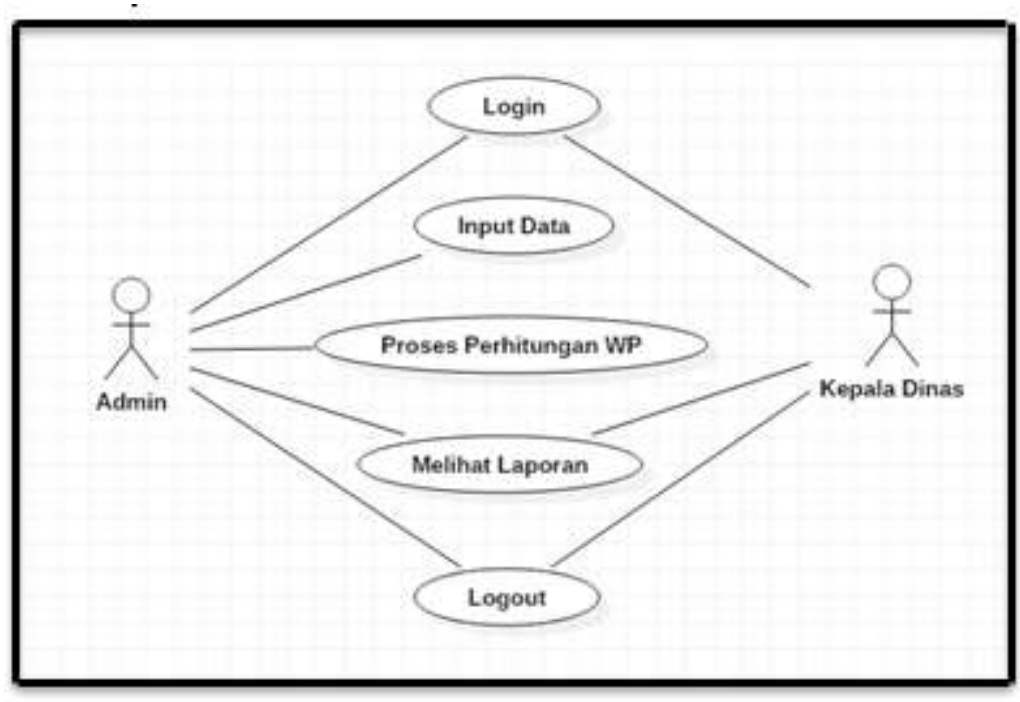

Gambar 4. Uses Case Diagram 


\section{b. Class Diagram}

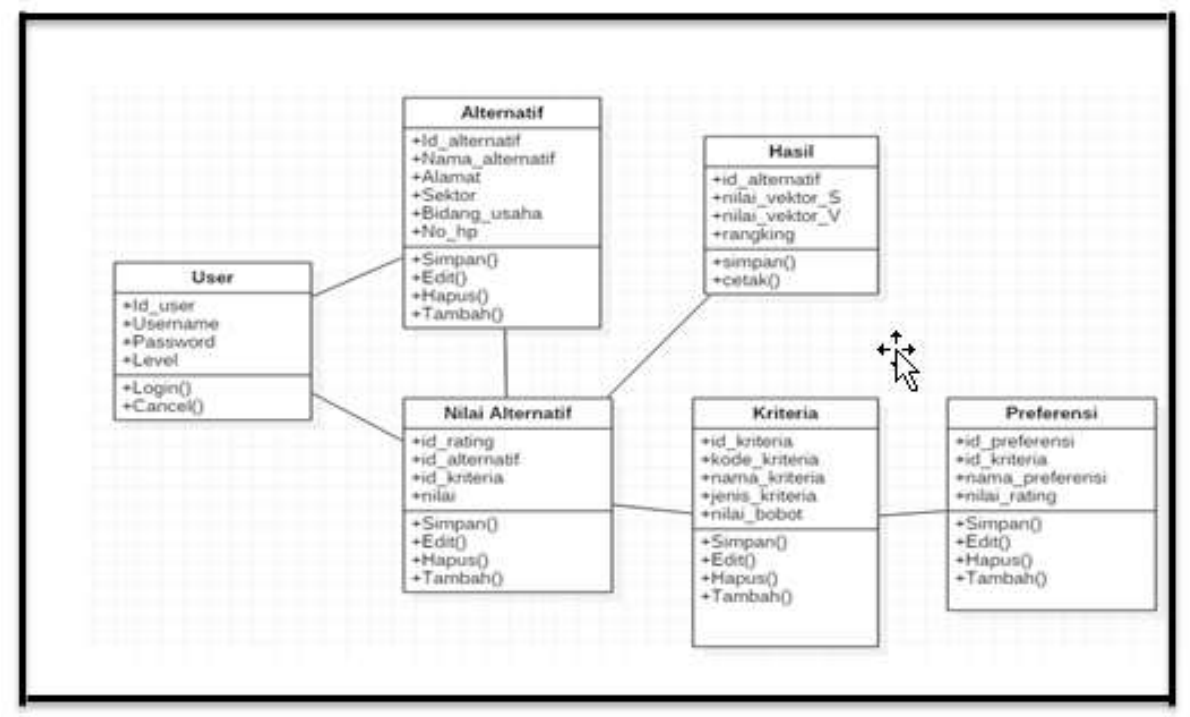

\section{Gambar 5.Class Diagram}

\section{KESIMPULAN}

a. Kesimpulan

Berdasarkan uraian dan pembahasan pada bab-bab sebelumya, maka dapat disimpulkan bahwa :

1. Untuk membangun sistem pendukung keputusan perusahaan yang berprestasi dalam sektor industri dengan metode weighted product, langkah pertama yang dilakukan adalah menentukan kriteria dan alternatif perusahaan yang akan di bandingkan, kemudian data tersebut akan dihitung menggunakan metode weighted product, dan hasil perhitungan berupa rangking alternatif yang telah diurutkan dari nilai alternatif terbesar sampai dengan nilai alternatif terkecil. Alternatif yang memiliki nilai terbesar merupakan alternatif perusahaan yang berprestasi.

2. Variabel dalam penelitian ini memiliki enam acuan variabel penilaian dengan masing-masing nilai bobot yaitu penanaman modal 5, LKPM 4, jumlah tenaga kerja 3, pengelolaan limbah 2, kewajiban sosial 2 dan jenis gaji 1.

3. Dari hasil pengujian kelayakan sistem bahwa pengujian yang dilakukan oleh pengguna mendapatkan hasil 76,66\%. Maka dapat disimpulkan berdasarkan perhitungan skala likert sistem tersebut dapat membantu manajemen dalam proses penentuan perusahaan yang berprestasi. 


\section{b. Saran}

Berdasarkan kesimpulan dan analisis yang telah dikemukakan, maka diajukan beberapa saran untuk penelitian berikutnya, yaitu :

1. Dalam penelitian ini hanya mencakup sedikit data perusahaan yang dipakai, akan lebih baiknya bila penelitian selanjutnya mencakup seluruh data perusahaan dalam semua sektor perusahaan yang ada di Kabupaten Sukabumi.

2. Kemudian dalam penelitian selanjutnya penulis mengharapkan metode weighted product ini dapat dibandingkan dengan metode lainnya sehingga dapat menemukan metode terbaik dalam studi kasusnya.

3. Dalam sistem ini sistem pendukung keputusan yang dibuat adalah berbasis web, penulis mengaharapkan kedepannya ada pengembangan dalam sistem pendukung keputusan ini dalam bentuk mobile android atau platform lainnya.

\section{DAFTAR PUSTAKa}

[1] Wiwied Wahyu Ramadhani "Sistem Pendukung Keputusan Dalam Pemilihan Karyawan Terbaik di PT. Smartlink Global Media dengan Metode Weight Product”. Skripsi Jurusan Informatika Fakultas Komunikasi dan Informatika Muhammadiyah Surakarta, April 2017.

[2] Nasrun Marpaung, Masitah Handayani, Rolly Yesputra "Sistem Pendukung Keputusan Pemilihan Dosen Terbaik dengan Metode Weighted Product (WP) Pada Stmik Royal” jurnal Sistem Informasi, STMIK Royal, September 2018.

[3] Guntur Maha Putra1, Novica Irawati “Analisis Pemilihan Handphone Rekomendasi dengan Metode Weighted Product” jurnal Sistem Informasi, STMIK Royal, September 2018.

[4] Cicik Sulastri, Sri Siswanti, Andriani KKW "Sistem Pendukung Keputusan Penilaian Dosen Berprestasi Menggunakan Weighted Product (WP) di STIKES Alma Ata Yogyakarta” jurnal TIKomSiN

[5] Miswan Gumanti, Oktafiani, Muhamad Muslihudin "Decision Support System To Determine Quality Traditional Spice For Making Turmeric Acid Using Weight Product Method” jurnal STMIK Pringsewu Lampung

[6] Dyah Pratiwi, Juliana Putri Lestari, Dewi Agushinta R. "Decision Support System to Majoring High School Student Using Simple Additive Weighting Method" Department of Information System, Gunadarma University, Indonesia, Apr 2014.

[7] Osdirwan Osman "Buku Pintar Microsoft Excel”. 
[8] Prof. Dr. Sri Mulyani, Ak., CA "Sistem Informasi Manajemen Rumah Sakit Analisis dan perancangan” 2017.

[9] Dona, Kiki Yasdomi, Urfi Utami "Sistem Pendukung Keputusan Karyawan Terbaik Menggunakan Metode Weight Product (WP) (Studi Kasus : Universitas Pasir Pengaraian)". Jurnal Program Studi Sistem Informasi Fakultas Ilmu Komputer Universitas Pasir Pengaraian, Juli 2018.

[10] Anita Rahmawati,, Yuli Astuti2 “Implementasi Weighted Product Untuk Penerimaan Karyawan”. Jurnal Informatika dan Manajemen Informatika Fakultas Ilmu Komputer, Universitas AmikomYogyakarta, Juni 2018.

[11] Zaenal Alamsyah "Sistem Pendukung Keputusan Menggunakan Metode Weighted Product Dan Simple Additive Weighting Terhadap Penerimaan Guru”. Skripsi Program Studi Sistem Informasi Universitas Nusa Putra Sukabumi, September 2018.

[12] Fauziah Ayu Kusumawardi "Implementasi Metode Weighted Product (WP) Sistem Pndukung Keputusan Seleksi Calon Karyawan di PT. Kebon Agung Surabaya”. Skripsi Jurusan Teknik Informatika Fakultas Sains dan Teknologi Universitas Islam Negeri Maulana Malik Ibrahim Malang, April 2016.

[13] Petricia Oktavia "Sistem Pendukung Keputusan Seleksi Penerima Beasiswa Dengan Metode Weighted Product Pada Smp Negeri 1 Parung Berbasis Web”. Jurnal Staf Pengajar Fakultas Teknik Prodi Teknik Informatika Universitas Pamulang, Tangerang Selatan, Banten, Juni 2018.

[14] Prof. Dr. Sri Mulyani, Ak., CA “Analisis Dan Perancangan Sistem Informasi Manajemen Keuangan Daerah Notasi Pemodelan UML” 2016.

[15] Ade Irma Nurfatmalia "Rancang Bangun Sistem Pendukung Keputusan Penilaian Kinerja Karyawan Sebagai Promosi Kenaikan Jabatan dengan Menggunakan Metode Perbandingan Eksponensial (MPE)”. Skripsi Program Studi Sistem Informasi Fakultas Sains dan Teknologi Universitas Islam Negeri Syarif Hidayatullah Jakarta, April 2015.

[16] Ristika Oktavina, Heribertus Himawan, M.Kom “Sistem Pendukung Keputusan Untuk Menentukan Pelanggan Terbaik Pada Tb.Bangun Jaya Menggunakan Metode Weighted Product (WP)”. Jurnal Teknik Informatika, Fakultas Ilmu Komputer, Universitas Dian Nuswantoro, Semarang.

[17] Heri Firmansyah "Sistem Pendukung Keputusan Menggunakan Metode Simple Additive Weighting Terhadap Pemilihan Calon Penerima Bantuan Rumah Tidak Layak Huni (RUTILAHU)”. Skripsi Program Studi Sistem Informasi Universitas Nusa Putra Sukabumi, September 2018.

[18] Arini T.Soemohadiwidjojo “KPI Key Performence Indicator” Untuk Perusahaan Industri. 